\title{
Topicality and Relevance of Janusz Korczak's Pedagogical Approach to Children and Their Upbringing
}

\begin{abstract}
Janusz Korczak's ideas and practical pedagogical achievements permanently went down in the history of Polish and world pedagogy. They have become a unique source of knowledge, ideas and inspiration in the quest for new educational solutions. His rich literary works, especially the pedagogical trilogy entitled How to Love a Child, is both a source of knowledge and inspiration for further reflection and research in the field of pedagogic sciences and an encyclopaedia of practical knowledge in the area of care, upbringing and education. The purpose of this article is to depict Korczak as a person, tutor, guardian, researcher-clinician and show his moral credibility confirmed with testimony to love. Not only does it present the topicality and importance of his pedagogical message but it also indicates the possibility of being a role model for many of today's tutors and teachers ${ }^{1}$.
\end{abstract}

\section{Keywords}

Janusz Korczak, child, upbringing, originality, relevance.

\section{Introduction}

Korczak's pedagogy has its roots in his experience as a doctor and is combined with love and practice, which made it become proven, fertile and fruitful knowledge. Its effectiveness results from the use of sound pedagogical and medical knowledge in child's upbringing, thereby allowing parents and

1 Cf. J. Balcerek, Janusz Korczak jako prekursor pedagogiki opiekuńczej, in: H. Kirchner, A. Lewin (eds.), Janusz Korczak. Życie i dzieło, Warszawa 1982, p. 185. 
carers to solve pedagogical problems the right way. Here is what Korczak wrote about in this respect: "Learning to make a diagnosis is fundamental in medicine. A student explores a number of individuals, he learns to look, and by recognizing the symptoms he learns to explain them, connect them and draw conclusions on their basis. If pedagogy wishes to follow the path clearly through medicine, it needs to develop parental diagnostics based on understanding the symptoms"'.

Janusz Korczak's pedagogical approach to children and their upbringing is formed maturely, which is why his pedagogy remains topical to this day. Topicality means that this approach has not become outdated with time. In order to get to know, understand and assess his philosophy properly, it seems essential to emphasize qualities that determine extraordinary topicality of Korczak's pedagogy. Korczak's approach is primarily marked by its originality and inventiveness, which is of great significance for challenges of contemporary pedagogy taken as science and practice.

\section{Topicality of Janusz Korczak's pedagogy}

Janusz Korczak's pedagogical approach to children and their upbringing was based on experience from his own family as well as endless contacts with children, whom he came across as a teacher and a doctor. He put his pedagogy into practice in two directions, namely in Orphans' Homes he had established and as well as through his writings. Topicality of Korczak's pedagogy is connected with his creed and the concept of children's autonomy ${ }^{3}$.

Contemporary pedagogy is noted for similar trends, as in the times of Korczak, that is it tends to create and organize impersonal relationships in the sphere of upbringing and education. They take the form of intellectual training in psychology of communication or such techniques, as commonly known concepts of education without failures. Using these models blindly and without reflection threatens the creative interaction with a child. A personalistic style and Korczak's dialogue between a child and his carer

2 J. Korczak, Wybór pism, selected by I. Newerly. D. Stępniewska (eds.), 1 edition, vol. 3, Warszawa 1958, p. 7.

3 Cf. W. Okoń, Wizerunki sławnych pedagogów polskich, Warszawa 1993, p. 235. 
become, today, a well-tried, appropriate and creative ways to build ties that guarantee the full development of a child.

Janusz Korczak, when looking at a child as an integral human being, was able to get to know and understand him. He did not seek for deficiencies in a child but was focused on his abilities; he was fascinated by children through the perspective of integral development and he highlighted this development. Korczak was against pedagogical intellectualism and emphasized the great value of spontaneity and vitality; he also believed that it is not a child that should fit the system, but on the contrary: the system should be adjusted to a child to correspond with his development ${ }^{4}$.

Another factor determining the topicality of Korczak's pedagogy is love. This is the fundamental principle and the basis for long-lasting bonds and relationships. J. Papuzińska ${ }^{5}$ notes that Janusz Korczak's cognitive activities are an integral part of the same upbringing process shaped by love. She also claims that love, as a value and pedagogical feature, is absent in modern pedagogy textbooks of any schools or specialization, while it is an extremely important factor in the pedagogical process. According to Papuzińska, this is one of the differences between modern pedagogy and Janusz Korczak's philosophy. The latter is neither fully used nor included in the mainstream of current research and development of new educational programmes and projects ${ }^{6}$.

Nowadays, getting to know a child is instrumental, detached from the whole process of the search for effective ways of shaping a child's personality. Love, in Korczak's pedagogy was the main reason to work with a child, to get to know him and understand him. Furthermore, it had became a source of inspiration for educational, pedagogical treatments aimed at recognizing a child's need and providing him with conditions for full development. Love was also the basis for treating a child as a human being. Therefore, especially today, Korczak's approach to a child and the upbringing process from the perspective of love allows for an appropriate assessment and selection of the right child-raising methods.

4 B. Smolińska-Theiss, Korczakowska idea prawa dziecka, „Pedagogika Społeczna” (2010), 3-4, p. 9-10; M. Majewski, Tajemnica żywotności pedagogicznej Jana Bosko i Janusza Korczaka, in: P. Poręba (ed.), Wartości pedagogiki Janusza Korczaka, Lublin 1979, p. 78.

5 Cf. J. Papuzińska, Podkultura dziecięca w twórczości Janusza Korczaka, in: H. Kirchner, O. Klecel (eds.), Janusz Korczak. Pisarz - wychowawca-myśliciel, Warszawa 1997, p. 45.

6 J. Papuzińska, Podkultura dziecięca w twórczości Janusza Korczaka, p. 151-152. 
The topicality of Korczak's pedagogy also manifests itself in (1) showing the proper pedagogic function of a family and (2) in the idea of children's rights. Upbringing is a family responsibility, it demands the moral ethos of individual members of a given family. Korczak distinguished four types of families: the first one is of a diagnostic nature; the second one is ideological; the third one is based on appearances and career-oriented and the fourth one constitutes a mature and responsible parenting environment ${ }^{78}$. According to Korczak, only the latter can fully assist a child in his development.

As far as children's rights are concerned, the right to respect is the central idea of the modern concepts of the protection of children's rights. This is expressed in the right to respect and love, the right to keep one's own secrets, develop and mature as well as the right to their own self being'.

Furthermore, Korczak's way to educate society in the field of pedagogy, based on dialogue and the joint search for solutions, remains topical to this day. The need for meetings, talks, educational books which do not provide ready-made solutions but can serve as a guide for parents and educators well acquainted with pedagogy and fully aware of child-raising related responsibilities and challenges, seems particularly fundamental nowadays ${ }^{10}$.

\section{Originality of Janusz Korczak's pedagogy}

The topicality of Janusz Korczak's pedagogical approach to a child and his upbringing is due in large measure to its originality. The term 'originality' refers to primal works, new or novel, and thus distinguished from reproductions, adaptation, or derivative works by some unusual, curious and rare aspects; original works or concepts exist independently, they are not based on previous models ${ }^{11}$. Thus understood, originality fully refers to Janusz Korczak's pedagogical approach and is associated with his personality

7 Cf. J. Bińczycka, Korczakowskie spojrzenie na rodzinę, in: J. Bińczycka (ed.), Korczakowskie dialogi, Warszawa 1991, p. 120-125.

8 Cf. J. Bińczycka, Korczakowskie spojrzenie na rodzinę, in: J. Bińczycka (ed.), Korczakowskie dialogi, Warszawa 1991, p. 120-125.

9 Cf. B. Śliwerski, Pedagogika Janusza Korczaka, in: Z. Kwieciński, B. Śliwerski (eds.), Pedagogika. Podręcznik akademicki (vol. 1), Warszawa 2003, p. 339-340.

${ }^{10}$ Cf. J. Balcerek, Janusz Korczak jako prekursor pedagogiki opiekuńczej, p. 186.

${ }^{11}$ Cf. S. Dubisz, Uniwersalny Stownik Języka Polskiego (vol. 3), Warszawa 2003, p. 1302. 
alone. He never forced himself on anyone - quite the contrary - : he attracted and won people's hearts with his kindness and spiritual values, which made him so reflective and able to reach deep corners of the human soul ${ }^{12}$. Korczak had an extraordinary ability to listen to a child. He listened to him as a scientist $\mathrm{t}^{13}$ and as a personalist, although he did not call himself $\mathrm{so}^{14}$. That patient, accurate and in-depth search for the truth about a child led him to recognizing and understanding a child as a human being ${ }^{15}$.

$\mathrm{He}$ discovered a child's psychological traits such as sensitivity, perceptiveness, patience, confidence, the ability to dream, the need to learn, play, work, rest, the need for order as well as for harmonious and creative fun, spiritual growth and experiencing emotions ${ }^{16}$. Recognition of the above characteristics in a child led him to a belief about deep intentionality and rationality of all behaviours of a child; such rationality is involuntary, unconscious and even though adults do not comprehend it, it remains in conformity with the natural order of things ${ }^{17}$.

Janusz Korczak presents a child integrally. Therefore, a child has a complex ontological, ethical, axiological, psychological, religious, and educational structure. Hence he is legally entitled to fully participate in the society's life. Thus he discovered that the humanity of a child involves

${ }^{12}$ Cf. M. Majewski, Tajemnica żywotności Jana Bosko i Janusza Korczaka, p. 74.

${ }^{13}$ A. Sobolewska, Sto masek, sto ról, „Midrasz” 12 (68) (2002), p. 7.

${ }^{14}$ Cf. K. Ablewicz, Janusza Korczaka personalizm ponadwyznaniowy, p. 223.

${ }^{15}$ Cf. K. Ablewicz, Janusz Korczak-wolność-wychowanie, in: F. Adamski (ed.), Wychowanie na rozdrożu. Personalistyczna filozofia wychowania, Kraków 1999, p. 15-23, E. Dauzenroth, Janusz Korczak. Życie dla dzieci, Kraków 2005, p. 99; A. Gurycka, Portret wychowawcy: Janusz Korczak, „Psychologia w szkole”, Kielce, (2005) nr 1, p. 76; H. Kirchner, Korczak - pisarz, In: H. Kirchner, O. Klecel (eds.), Janusz Korczak. Pisarz-wychowawca-myśliciel, Warsaw 1997, p. 10; B. Ignera, Czynnik religijny w działalności wychowawczej Janusza Korczaka, in: P. Poręba (ed.), Wartości pedagogiki Janusza Korczaka, Lublin 1979, p. 89; M. Majewski, Tajemnica żywotności Jana Bosko i Janusza Korczaka, p. 69; St. Cz. Michałowski, Personalizm ponadwyznaniowy w pedagogii Janusza Korczaka, in: P. Poręba (ed.), Wartości pedagogiki Janusza Korczaka, Lublin, p. 90; J. Niewęgłowski, Janusz Korczak - dziecko i Bóg, „Seminare” 19 (2003), p. 324; B. Smolińska-Theiss, Obraz dziecka i dzieciństwa a pedagogikaIn: in: F. Adamski, Edukacja wobec dylematów moralnych wspótczesności, edition, Kraków, p. 53-54; K. Starczewska, Świadomość religijna Janusza Korczaka, in: H. Kirchner, O. Klecel (ed.), Janusz Korczak. Pisarz - wychowawca - myśliciel, Warsaw 1997, p. 231; J. Tarnowski, Janusz Korczak dzisiaj, Warsaw 1990, p. 62-63; W. Theiss, Korczak - nowa antropologia wychowania (international conference), „Problemy Opiekuńczo-Wychowawcze”, 9, p. 55.

${ }^{16}$ Cf. D. Rusakowska, Janusz Korczak o szkole. Poglady - oceny - doświadczenia, Warsaw 1989, p. 61-62.

${ }^{17}$ Cf. J. Papuzińska, Podkultura dziecięca w twórczości Janusza Korczaka, p. 165. 
specific characteristics attributable to human being, including, in particular, the special value and dignity of the human person ${ }^{18}$.

Based on these premises, Korczak created an integral, personal and subjective vision of a child, identifying and pointing to specific personal traits of a child as a human person ${ }^{19}$. Children are material and spiritual beings, they have a sense of identity; they are also individual, unique, and free ${ }^{20}$. Because a child has somatic, mental, spiritual and religious dimensions, he becomes a rational being: autonomous, self-conscious, free, able to know the truth, to live in love and conduct dialogue with the world and environment, able to take control over the nature and to manage his own life. Profound transcendence, humanity and love have become part of the presented child as a rational being $^{21}$. A child is a full-fledged human being just like an adult, differing only in accumulated experience and the ways of acquiring it. Underlying the personalistic approach to a child is the belief that a child is a full human person, a value in himself, supreme good created by God (this is how a child is perceived from the supernatural and transcendental perspective $)^{22}$.

It seems that in Korczak's mind, the ontological and ethical-axiological dimensions of a child as a human being, constitute the main basis for drawing a complete and original portrait of a child. These two dimensions determine the status of a child and link together all qualities and attributes of a child into an integral system of sustainable and dynamic nature. The ontological dimension manifests itself in a child's being: a child is a human, a person, a durable and permanent being, whereas ethical-axiological dimension shows the dynamic nature of the process of becoming a person; underlying this process are: human experience, thought and action.

Korczak does not separate these two realities for it would mean the reduction of human nature. He treats them as an integral whole, which shows

${ }_{18}$ T. Kukołowicz, Szacunek dla wychowanka w ujęciu J. Korczaka, in: T. Kukołowicz (ed.), Teoria wychowania, Stalowa Wola 1996, p. 61.

${ }^{19}$ Cf. J. Korczak, J. Wybór pism (vol. 3.), p. 414.

${ }^{20}$ K. Ablewicz, Janusz Korczak - wolność - wychowanie, p. 18.

${ }^{21}$ A. Rynio, Integralne wychowanie w myśli Jana Pawła II, Lublin 2004; Cf. A. Zych, Dziecko w utworach Janusza Korczaka, „Przemiany” (1979) nr 6, p. 13.

${ }^{22}$ B. Ignera, Czynnik religijny $w$ działalności wychowawczej Janusza Korczaka, p. 92; B. Smolińska-Theiss, Korczakowska idea praw dziecka, p. 12; Czynnik religijny w działalności wychowawczej Janusza Korczaka, p. 92; B. Smolińska-Theiss, Korczakowska idea praw dziecka, „Pedagogika Społeczna” (2010) 3-4, p. 12. 
and defines the essence of humanity of a person. Childrenare human beings whilst at the same time become human person as they experience themselves and the world in an ethical and axiological way.

When exploring the essence of the humanity of a child, Korczak recognizes a number of rights that a child is entitled to, simply because a child is a human being. B. Smolińska-Theiss notes that the originality of Korczak's approach to children's rights is connected with the fact that he understood and propagated the idea that children have their rights because they are human beings, not because adults granted them these rights. The rights express respect for a child, for his childhood. Children's rights are not created by history or culture and childhood is not determined by culture or psychology; it is founded on longlasting values and rights that each person is entitled to; hence their references in axiology and theology. Korczak's interpretation of these rights is a cry for the proper understanding of the essence of a child and his place in the society of adults.Children's right to be what they are, is the right of all persons. And because children are persons, they deserve respect. Korczak particularly distinguished the right to die, which, in a special way reveals the axiological nature of human life ${ }^{23}$.

$\mathrm{K}$. Ablewicz notes that the 'right to die' reveals premises proving the human nature of a child. Korczak shows that only in the context of death can one read the full truth about the person. This is manifested in the irreducible experience of a child dealing with one's self and the world. He also points out that such an experience (construed as development) is conditioned by human freedom, and where freedom is, there is also a risk, an imponderable risk - the loss of care. A child's life goes on in the same world as an adult's life, hence a child's existential experiences have the same attributes. The nature of a child manifests itself dynamically, especially when it comes to the right to $\mathrm{die}^{24}$.

Furthermore, B. Smolińska-Theiss notes that there are specific questions arising around Korczak's idea of this right, for instance: does he mean the dignity of the end of a child's life, or child's path that leads to death? Does Korczak remind us of a child's right to die or the right to life ending with death? Is this right granted or given back to a child, or is a child entitled to it? B. Smolińska-Theiss rightly goes on to say that Korczak asks questions

${ }^{23}$ Cf. B. Smolińska-Theiss, Obraz dziecka i dzieciństwa a pedagogika a pedagogika..., p. 53.

${ }^{24}$ Cf. K. Ablewicz, Janusza Korczaka personalizm ponadwyznaniowy, in: Wychowanie na rozdrożu, p. 226-227. 
about a child as a human; these questions touch the essence of life and death of a child as a person ${ }^{25}$.

The originality of Janusz Korczak's approach to a child manifests itself firmly in the ontological and ethical-axiological dimensions: great emphasis is placed on the aspect of religiousness, his experience and actions in terms of individuality, freedom, love and subjectivity. The religiousness of a child is part of human nature. Korczak links religiousness with transcendence; a child is sacred to him. He sees the Creator's plan in children; they are religious beings, thereby, they become to Korczak a sign of God and God's presence. Morally unblemished, the child is the most perfect image of God's plan, which is why a child becomes capable of pointing to God and leading another man to Him. A child is a person who is best expressed through transcendence. He easily establishes contact with God, relates himself and his life to God, longs for Him, seeks contact with Him. God and His love, for a child, constitute essential factors in motivation for action and self-improvement, while prayer is the way leading to this relationship and the prime moment to develop the inner 'self'. Therefore, all actions within Korczak's pedagogy were permeated with religious content and centred around getting the hidden good out of a child and shaping the beauty of human being ${ }^{26}$.

Korczak combines a child's religiousness with the ontological be-ing and axiology of humanity. The originality of such an approach lies in the fact that the consistency between religiousness, be-ing and axiology in a child had been finally noticed. Religiousness is an integral part of human nature, which makes people capable of going beyond in their be-ing. In terms of the axiological dimension of human life, religiousness enables a child to develop towards ethical, moral and spiritual maturity ${ }^{27}$. A child is a rational being: he is capable of acting, creating and transforming himself, not only from the outside, but also from the inside through his own experience. Korczak's understanding of the human being reveals, in a child, what is irreducible and helps interpret his self-experience. This is possible provided that a child and

${ }^{25}$ Cf. B. Smolińska-Theiss, Obraz dziecka i dzieciństwa a pedagogika..., p. 54.

${ }^{26}$ Cf. B. Ignera, Czynnik religijny w działalności wychowawczej Janusza Korczaka, p. 90; B. Smolińska-Theiss, Obraz dziecka i dzieciństwa a pedagogika..., p. 54. Cz. Michałowski, Personalizm ponadwyznaniowy w pedagogii Janusza Korczaka, p. 99.

${ }^{27}$ St. Cz. Michałowski, Personalizm ponadwyznaniowy $w$ pedagogii Janusza Korczaka, p. $102-103$. 
an educator develop a deep and unique relationship and will watch each other in this relationship ${ }^{28}$.

Such a self-experience is connected with corporeality and spirituality of a child. This two-dimensional perspective of human life in the plane of action becomes a space for development; hence Korczak uses it as a principle underlying child-raising and self-educatory work. The spiritual and corporeal nature of the person gives children the sense of reality and physicality; it proves their own presence, allows them to experience the joys and sorrows of life, enables them to go deep into themselves and experience themselves not only from the inside, but also from the outside. K. Ablewicz notes that Korczak, probably, saw this phenomenon of a man in himself as well. There are signs supporting this thesis in the novel entitled Bobo, particularly in parts describing Bobo's first struggle with himself ${ }^{29}$.

According to Korczak, experience is an act of human action. It is closely bound to individuality and human freedom, that is, to elements which form the ontology and axiology of human existence. These two human characteristics are closely connected with each other and mutually dependent. Anna Sobolewska ${ }^{30}$ notes that Korczak's concept of a child's inner freedom is connected with child's individuality. Every child is different and needs individual methods in order for one's personality to shape and develop. In this perspective, if one child is to be a nature explorer and another is to be a reformer, the first will demand more freedom, while the latter will seek reinforced authority and ready-made patterns. Thus, a child with a solitary disposition will need completely different forms of support in his development to a group leader etc.

Korczak defines individuality as a characteristic quality of humanity created by the human genotype. Elements that constitute this genotype include: temperament, predispositions, abilities, personality, and a rich diversity of personal experience ${ }^{31}$. He sees identity in a child's individuality ${ }^{32}$. Furthermore, individuality conditions the understanding and acceptance of a child in the area of freedom. Identity is embedded in the nature of a child

\footnotetext{
${ }^{28}$ Cf. K. Ablewicz, Janusza Korczaka personalizm ponadwyznaniowy, p. 224.

${ }^{29}$ Cf. K. Ablewicz, Janusza Korczaka personalizm ponadwyznaniowy, p. 225.

${ }^{30}$ A. Sobolewska, Dziecko - sto masek, sto ról, p. 7.

${ }^{31}$ Cf. J. Korczak, Wybór pism, vol. 3. p. 98.

${ }^{32}$ H. Kirchner, Korczak-pisarz, p. 18.
} 
in the form of a desire for freedom, has its source inside an individual ${ }^{33}$, is connected with human personality as it manifests itself always and only in a manner typical of a given person.

According to Korczak, individuality, guaranteed and respected, is not in contradiction with discipline. The latter is harmonized with a child's individuality, his needs, abilities and predispositions, thereby becoming the basis for wise cooperation in gaining personal experience. Korczak's look at human freedom in a child is connected with purposefulness of child's existence. He believed that freedom does not mean a child is allowed a lot of leeway, but that it is given to people for some specific purpose. A. Sobolewska ${ }^{34}$ notes that inner freedom is, in first place in child-raising, because only a free man is capable of achieving spiritual maturity.

Love is another aspect of a child's life, heavily exposed in Korczak's philosophy of upbringing. He attributes an overriding pedagogical function to love, thereby making it unprecedentedly important. Understanding the essence of love in the process of upbringing is connected with his personal experience of love from childhood. Thanks to this experience, love had become a paramount point of reference in the life devoted to a child. Korczak's affection for a child is similar to the idea of Christian love ${ }^{35}$. Such love was very much like Christ's love ${ }^{36}$ or Samaritan love ${ }^{37}$ Thus it was a personal emotion shown to a child, directed to the best interest of a child and manifested in trust, in affectionate and fatherly approach to the child and it's needs. Relations between Korczak and children were somewhat parental, in imitation of ties between parents and their descendants.

He was convinced that only spiritual, parental love oriented to best interest of a child may help adults understand a child and assist in his development; this is why love is a fundamental principle underlying all child-related references and educational actions. In his correspondence, in confessions made to friends and also in the writings about the role of an educator, especially in the second part of the How to Love a Child trilogy (entitled Dormitory), Korczak clearly

${ }^{33}$ Cf. A. Sobolewska, Dziecko - sto masek, sto ról, p. 6.

${ }^{34}$ Cf. A. Sobolewska, Dziecko - sto masek, sto ról, p. 6.

${ }^{35}$ Cf. B. Wojnowska, Wczesna publicystyka Janusza Korczaka, in: H. Kirchner, O. Klecel (eds.), Janusz Korczak. Pisarz - wychowawca-myśliciel, Warszawa 1997, p. 43.

${ }^{36}$ J. Tarnowski, Janusz Korczak dzisiaj, p. 95; K. Starczewska, Świadomość religijna Janusza Korczaka, p. 231.

${ }^{37}$ M. Łobocki,Altruizm a wychowanie, Lublin 1998, p. 129. 
points to love as the main motif of pedagogical actions. It should be a wise love $^{38}$, constantly practised and deepened in the form of affirmation towards oneself, God, child and the world. In a number of retrospective descriptions, especially in How to Love a Child, Korczak describes countless child-raising related problems which were properly solved through love. Contrary to the, then, rigorous educational systems, in which a tutor expected highly from his charges, in Korczak's pedagogy, upbringing became equal to giving other people the most precious value, which is love.

It seems that Korczak, by introducing love as the basic pedagogical principle and psychopedagogical category into the relationship between a child and an educator, shows that a child can be best understood and comprehended in love,. Since his approach was love-based, he was able to see in a child many predispositions and abilities of crucial importance to his development; he saw innate and spiritual qualities, including the natural ability to love and sympathize, much exceeding adults' predispositions to do $\mathrm{so}^{39}$.

Another factor, which determines the originality of Korczak's approach to a children and their upbringing, pertains to subjective presentation of a child. A child, in his pedagogy, is a sensitive and active entity which acquires experience of being someone ${ }^{40}$. In early interpretations, a child's subjectivity was construed in opposition to being an object of the upbringing process, whereas subjectivity in Korczak's philosophy emerged in contrast to the social, institutional or task-oriented structures, into which a child's identity was squeezed. This is clearly illustrated by the, so-called, pedagogy of care, the core of which was the institution of a children's home with its tasks, functions, authority, medical units etc.

Discovering a child's subjectivity in pedagogy, particularly in care pedagogy, was possible because a child's needs were recognized. They were determined on the basis of classic theories of human needs and connected with upbringing-related activities (for example, needs for securitywere often coupled with needs for care). B. Smolińska-Theiss notes that such an approach has little in common with subjectivity, since it does not consider the questions

${ }^{38}$ E. Wysocka, Milość jako kategoria psychopedagogiczna - analiza teoretyczna i empiryczne egzemplifikacje, „Pedagogika Społeczna” (2010), 3-4, p. 32-33; B. Smolińska-Theiss, Janusz Korczak-pedagogiczne transgresje, p. 9.

${ }^{39}$ B. Wojnowska, Korczak: nowa antropologia wychowania, p. 9.

${ }^{40}$ A. Gurycka, Korczakowskie inspiracje, Warszawa 2002, p. 116; K. Ablewicz, Janusza Korczaka personalizm ponadwyznaniowy, p. 224. 
of the type of these needs or their source (whether they are generated by a child or by the system of care and education $)^{41}$.

According to Korczak, subjectivity, as a pedagogical idea, means a discovery and support of the child and various communities. Korczak's child experiences himself as an individual that feels different emotions and goes through various stages of life; such child changes, gets bigger or smaller, arranges the world around him in a contemplative way. He discovers, in himself, his own spirituality and personality with astonishment and reflection; he uses the possibility of access to what will always be a mystery to others. This 'irreducible mystery' becomes a source of knowledge about himself, thus a child experiences his own psycho-spiritual identity. K. Ablewicz notes that Korczak, in his reflections on the deepest human nature, paved the way which was later followed by Karol Wojtyła and basically, personalists: he shows that the essence of humanity lies in a child himself, not in the world ${ }^{42}$.

In the child-adult or charge-tutor relationships, both parties are active ${ }^{43}$, whereas each of them remains a separate entity. This implies a dialogue in which the roles of particular participants thereof, are different as they result from the nature of the process of upbringing. This personalistic approach, in which a child becomes a subject in upbringing ${ }^{44}$, allowed Korczak to create an original, warm and friendly atmosphere in his Homes. The model of upbringing was based on love and respect for a child, and its task was to bring out the best of a child. The role of an educator, one's philosophy of life, one's readiness to serve children and the entire personality filled with prayer were also important here ${ }^{45}$. Korczak assumed that, before a person starts to bring up a child in the name of the upbringing ideal, before he probes into the philosophy of upbringing and before he recognizes what is good in a given situational context, he should first reach out to the human experience of a child ${ }^{46}$.

${ }^{41}$ B. Smolińska-Theiss, Obraz dziecka i dzieciństwa a pedagogika ..., p. 49.

${ }^{42}$ Cf. K. Ablewicz, Janusza Korczaka personalizm ponadwyznaniowy, p. 224-225.

${ }^{43}$ Cf. B. Smolińska-Theiss, Obraz dziecka i dzieciństwa a pedagogika ..., p. 50.

${ }^{44}$ B. Matyjas, Koncepcja wychowania Janusza Korczaka, in: T. Pilch (ed.), Encyklopedia Pedagogiczna XXI w., vol. 2, Warszawa 2003.

${ }^{45}$ A. Gurycka, Portret wychowawczy: Janusz Korczak, p. 71-73.

${ }^{46}$ Cf. K. Ablewicz, Janusza Korczaka personalizm ponadwyznaniowy, p. 226. 


\section{Inventiveness of Korczak's approach to a child and his upbringing}

Inventiveness is closely associated with Korczak's activities, with the practical implementation of his pedagogical plan, which was crowned with opening and running two homes for children: 'OurHome' and 'Orphans' Home'. Inventiveness and innovative mean going beyond previous achievements in any field, acting in a visionary, non-traditional way and introducing something new ${ }^{47}$. According to this definition, one might distinguish several factors proving the inventiveness of Korczak's pedagogical approach to a child and his upbringing.

His reformatory pedagogical actions constituted a breakthrough in pedagogy and initiated a new approach to problems of raising orphaned and abandoned children. Korczak's idea of creating foster family environment for children was ahead of the possibility of its implementation in the social and political conditions of that time. The innovative concept of two homes for children, namely 'Orphans' Home' and 'Our Home', consisted in the specificity of their organization, which was based on family system. An older child became a guardian of a younger one, which created a kind of bonds in imitation of relationship between siblings and other family members. A child was not only a person, a subject in the relation to himself and another child but also someone who could experience family relationships, family warmth and passes on such experiences to others. According to memories of children brought up in Korczak's Homes (collected in the book entitled Memories of Janusz Korczak), these relationships often allowed them to compensate emotional defects and meet their needs for love, acceptance, being a member of some community.

Korczak also created a modern system of care-based upbringing in care facilities; underlying this model was the belief that it is possible to help a child develop his personality and potential through self-improvement. Therefore, the emphasis was placed on self-upbringing: orders and prohibitions of all kind were replaced with child's freedom and autonomy ${ }^{48}$. Korczak developed a concept of Self-government, within which he was successfully using many new methods of pedagogical impact. They concerned a child's effort to shape his own character towards refining morality, overcoming bad tendencies and

47 St. Uniwersalny Stownik Języka Polskiego, vol. 3, p. 1026.

${ }^{48}$ B. Balcerek, Janusz Korczak jako prekursor pedagogiki opiekuńczej, p. 184-185. 
developing good habits. One of such methods were the famous 'facilities' for boys ${ }^{49}$. Korczak integrated the whole upbringing process with religious education, which is why religious content permeated the pedagogy, thereby creating a coherent child-raising system. Including the religious aspect in the upbringing process allowed the full development of the sacred in a child, as well as relationship with God, since, to Korczak, these were the two deepest and most important spheres of life ${ }^{50}$.

The originality of Korczak's approach also consisted in showing new perspectives in the child-educator relationship. He claimed that not only a child learns from an adult but also an adult learns from a child. This was not, however, a symmetric process. According to Korczak, a child's subjectivity was connected with an adult's subjectivity. The competence and tasks of an adult are different from those assigned to a child. A child opens up, before an adult, a section of his world, while an adult listens to this world, tries to get to know and understand $i^{51}$. Everything is based on the confidence in a child, while this confidence provides the grounds for dialogue to emerge. In Korczak's times, when one upbringing model consisted in autocratic parenting style and the other model in freedom and spontaneity, without adults' care and supervision, confidence-based pedagogy was the new and original form of upbringing relations.

Rev. J. Tarnowski distinguishes several types of dialogue in Korczak's pedagogy: firstly, a matter-of-fact, substantive dialogue which is associated with learning and gaining experience and is comprised of three relations: one is traditional, two others are new. In traditional pedagogical system, an educator is a dominant link, whereas in the new one, a child dominates and becomes an equal partner in a dialogue with his tutor ${ }^{52}$.

Secondly, he mentions the personal dialogue involving a meeting of two entities. It is based on love, respect and trust. Korczak himself was the best example of a model adult, caregiver, friend, simply a man identifying himself with a child and the world of his emotions and experience. The third form of dialogue used by Korczak is existential in nature; it involves a meeting of two

${ }^{49}$ M. Łobocki, $A B C$ wychowania, Lublin 1999, p. 60.

${ }^{50}$ Cf. St. Cz. Michałowski, Personalizm ponadwyznaniowy w pedagogii Janusza Korczaka, p. $97-103$.

${ }^{51}$ B. Smolińska-Theiss, Obraz dziecka i dzieciństwa a pedagogika..., p. 50.

52 J. Tarnowski, Janusz Korczak dzisiaj, p. 69-86. 
people in their deepest 'self', people of the same existential rank. This type of dialogue is comprised of complicity, co-suffering and co-joy. It is based on the principle of respect for personal freedom and social engagement of a child.

Korczak's personalistic approach to children led to the acceptance of a charge as a person, neighbour and the second 'self'. Therefore, he created a new model of pedagogical relationships, a model based on co-upbringing and co-existence ${ }^{53}$. Such a model involves a new type of tutor, who is a person who is professionally prepared, not only intellectually and psychologically, but above all, personally and morally mature. J. Bińczycka notes that this approach is complete andholistic, thereby giving maximum chances of success in child-raising. Well matched educators were one of the conditions for such pedagogical success. What was essential in their attitude was maturity, most fully expressed in love. Such love was to be patient, ready for unconditional acceptance, capable of forgiving, full of faith in a child's willingness to work on his own character, consequent and based on properly selected educational methods corresponding with individual needs and abilities of a given charge. According to Korczak, a tutor himself is an honest, fair and righteous person, with a clear conscience, leading a morally blameless life. Only such a person can show a child the direction of moral sensitivity development and make him willingly head in this direction. Intellectual skills, abilities, mental and emotional predispositions, organizational skills, personal skills, previous practice and experience are important too, but they are somewhat relegated to the second place when working with a child. A mature educator, whom Korczak calls 'rational', is noted for reflexivity, willingness to spiritual development, readiness and ability to change one's own behaviour and attitudes for better ones ${ }^{54}$.

The originality of Korczak's approach to children and their education is also manifested in a method of acquiring knowledge about the child, which is essentially based on conscientious and reliable observation underlying the pedagogical experience ${ }^{55}$. Korczak borrowed research techniques and scientific ways of thinking from medicine ${ }^{56}$ (the process of acquiring factual p. 110.

${ }^{53}$ St. Cz. Michałowski, Personalizm ponadwyznaniowy w pedagogii Janusza Korczaka,

${ }^{54}$ Cf. J.Bińczycka, Spotkanie z Korczakiem, p. 88-90.

${ }_{55}$ H. Miska, Działalność praktyczna jako główne źródło wiedzy Janusza Korczaka o dziecku, in: H. Kirchner, A. Lewin (eds.), Janusz Korczak. Życie i dzieto, Warszawa 1982, p. 158.

${ }^{56}$ W. Okoń, Wizerunki sławnych pedagogów polskich, Warszawa 1993, p. 234. 
knowledge was based on medical method of diagnosing and understanding the symptoms) and used his knowledge and experience in the field of both pedagogy and medicine. A number of records and observations of life of infants, mentioned particularly in The Child in the Family (one of the parts of the trilogy How to Love a Child) as well as in the novels Educational Instants and Bobo, prove what an attentive observer he was and how accurate his conclusions and diagnoses of children's behaviour and development were. The attitude of an astute researcher and indefatigable clinician allowed him to select appropriate methods of correcting defects, forming positive personal traits in a child and developing capabilities.

Thanks to the diagnostics he used in his research work dedicated to a child, Korczak became the first specialist in pedagogy and child development who, in a scientific manner, pointed to adults' their ignorance (resulting from lack of reliable knowledge) in relation to a child. As one of the first experts in child development, he demanded establishing clinics in order to conduct scientific research and create conditions to observe children in terms of their health, behaviour, developmental needs etc. ${ }^{57}$.

According to Korczak's philosophy, the process of raising a child based on personal and subject-related vision was grounded on carefully developed purposes of upbringing, which, because of their content, make this process innovative and unique. All goals, both principal and individual ones, were focused on the axiological and ethical development of a child, whereby the principal, ultimate goals concerned undisputed universal values such as justice or the pursuit of peace. Individual goals, however, were used to develop particular personal traits such as endurance, willpower, courage, altruism, love, sense of duty, and responsibility ${ }^{58}$. Thus motivated upbringing led a child to work on himself, gave meaning to such work and stimulated positive attitude.

Janusz Korczak was also an original writer, probably so because he was also a pedagogue. Pedagogy provided him new ample material to convey to society via his literary works. A child and his upbringing were in the centre of his literary interests. Freshness of his pedagogical writing results from introducing observation into literature. He interspersed his thoughts with p. 31 .

${ }^{57}$ Cf. B. Śliwerski, Pedagogika dziecka. Studium pajdocentryzmu, (1 ${ }^{\text {st }}$ ed.), Gdańsk 2007,

${ }^{58}$ Cf. D. Rusakowska, Janusz Korczak o szkole. Poglady - oceny-doświadczenia, p. 49. 
results of such observations and related reflections, which set the main tone of his pedagogical writings. Therefore, he created a new, unconventional form of dissemination of pedagogical knowledge in society, and his works of fiction, articles, letters, conversations, presented in, thus far an unprecedented form, enjoyed enormous popularity and interest ${ }^{59}$.

H. Kirchner notes that Korczak managed to introduce a child into literature in a legible and understandable manner thanks to his colourful, emotional, narrative, purposeful, concise, and humorous stories containing a bit of grotesque, satire and parody. He also introduced dialect, the language of a child, thereby creating innovative literary forms (dialogues, narrative structure of the 'spoken' language, sayings). Unique properties of Korczak's literary language and the diversity of means of expression resulted in a remarkably visionary 'spoken novel'. He created a new genre: a dialogue between two individuals, namely a child and an adult ${ }^{60}$.

\section{The relevance of Korczak's approach to a child and his upbringing, to challenges of contemporary pedagogy and education}

Many signs of the contemporary crisis in upbringing correspond to the pedagogical problems of the first half of the 20th century, with which Janusz Korczak was faced as well. These problems still refer to the same phenomena that simplify and distort the idea and sense of upbringing; only nowadays, their status is different, and different terminology is used to describe them. One of the mistakes typical both of Korczak's times and today's reality is the so-called moral intellectualism, already mentioned herein. The surfeit and chaos of contemporary cultural proposals also pose a serious threat to a young person in achieving personal maturity and integration. Postmodern detachment of upbringing and education from the foundations of classical tradition, in its important normative points, ${ }^{61}$ increases internal chaos, leading a child or a young person to spiritual and mental confusion.

${ }^{59}$ Cf. J. Balcerek, Janusz Korczak jako prekursor pedagogiki opiekuńczej, p. 186; H. Kirchner, Korczak-pisarz, p. 8 and 12-13; W. Okoń, Wizerunki sławnych pedagogów polskich.

${ }^{60}$ Cf. H. Kirchner, Korczak-pisarz, p. 12-17.

${ }^{61}$ W. Brezinka, Wychowanie i pedagogika. W dobie przemian kulturowych, Kraków 2008, p. 15. 
Mistakes in modern upbringing are visible everywhere, in all areas of human existence. They become particularly apparent in such pedagogical institutions as family and school. It is family upbringing and school education that are presently marked by low efficiency, depersonalization and desocialization ${ }^{62}$.

In the $80 \mathrm{~s}$, I. Jundziłł ${ }^{63}$ wrote about the emergence of the social phenomenon of secondary orphanages. Modern mothers raise their children in a cold way, without showing signs of love, without caress, parental love and maternal tenderness. Pedagogy was transformed on a large scale into a propaganda of ideology devoid of common-sense basis; thus the subjectivity of a child was $\operatorname{los}^{64}$. Today, in the era of competition, education for career, the pursuit of success and desire to be the best, to win and dominate over others ${ }^{65}$, the following questions arise: whom or what is education intended for? What is it supposed to be like? What values should it focus upon, when modern civilization requires us to look at a child as if he was a small consumer (there are even opinions that children's specific culture and childhood are disappearing $)^{66}$ ?

It seems that, in such a situation, an anthropological breakthrough in pedagogy is necessary. Anthropological re-evaluation of educational actions should remain in close relationship with re-reference to the concept of the full human being, hence the child as well, with total respect for the child's dignity. This involves the necessity to reconstruct an education system based on the subjectivity of a person living in particular local and national community ${ }^{67}$. In order to meet the needs of modern society, both theorists and practitioners of upbringing must reflect on children and their upbringing in today's world, categorically opposing any model of life that

${ }^{62}$ A. W. Janke, Wizja człowieka współdziałajacego-pedagogiczna perspektywa przeobrażeń $w$ stosunkach rodziny $i$ szkoty, in: F. Adamski (ed.), Edukacja wobec dylematów moralnych wspótczesności (1 $1^{\text {st }}$ edition), Kraków 1999, p. 149.

${ }^{63}$ Cf. I. Jundziłł, Opieka nad dzieckiem w Polsce w świetle idei Janusza Korczaka, „Ruch Pedagogiczny" (1988) 1-2, p. 31-32.

${ }^{64}$ F. Adamski, Poza kryzysem tożsamości w kierunku pedagogiki personalistycznej, in: F. Adamski (ed.), Poza kryzysem tożsamości, Kraków1999, p. 11.

${ }^{65}$ Cf. T. Pilch, Pedagogika w poszukiwaniu swoich zadań i roli w budowaniu przyszłości, in: F. Adamski (ed.), Edukacja wobec dylematów moralnych współczesności ( $1^{\text {st }}$ edition), Kraków 1999, p. 66.

${ }^{66}$ B. Wojnowska, Korczak: nowa antropologia wychowania, p. 9.

${ }^{67}$ Cf. St. Sławiński, Szkolnictwo w Trzeciej Rzeczypospolitej na rozdrożu, in: Wychowanie na rozdrożu (1 ${ }^{\text {st }}$ edition), Kraków 1999, p. 77. 
leads to the loss of humanity ${ }^{68}$. Hence the need for a pedagogy which would show the meaning and beauty of the highest, universal values, as well as the sensitivity to the ethos of human being ${ }^{69}$. It is, therefore, necessary to develop the concept in upbringing that would strengthen in a child what is beautiful and the most important for development. This task is somewhat becoming a fundamental pedagogical duty and obligation for educators and parents to fulfil.

Janusz Korczak's pedagogy, centred around the highest and universal values, might serve as a way out of the today's educational crisis. Its relevance to contemporary child-raising is manifested in the topicality of Korczak's approach to a child and his upbringing, and the axiological timelessness of ideas arising from his creed. Rev. M. Majewski ${ }^{70}$ notes that the vitality of this pedagogy comes from the fact that it is less intellectual and organizational and more existential and situational. Korczak's pedagogy was developed in difficult conditions, and Korczak himself did not have adequate material facilities or pedagogical and didactic means, but his philosophy was almost organically connected with the life of a child and focused on the selfless dedication to a person. This is where its power lies. The topicality of Korczak's approach and practice depends primarily on internal values, among which a child himself, his life, happiness and well-being are crucial. Korczak's pedagogy has its root in children's needs, experiences and desires; it is strongly connected with the present and is able to influence the future. It is founded on undeniable values, becoming an inherent part of the era and the environment, and has many sympathizers and followers.

The importance of Korczak's approach to a child, and his upbringing, to the contemporary world results from particular vision of a child. It involves a solid concept of a child and childhood, grounded on truth and realism. Children are full human beings who have the ability to enhance their dignity by working on themselves in the process of self-education. Korczak's model of upbringing, construed as a process of liberation and opening up, is centred around the child as the highest value, and around values that shape ethical and moral

${ }^{68}$ Cf. M.. Tomczyk, Ideały $i$ wzory osobowe w ujęciu o. Jacka Woronieckiego (typescript), Lublin 2011, Archiwum KUL, p. 278.

${ }^{69}$ Cf. E. Kubiak-Szymborska, Kogo wychowujemy i jaki człowiek w kontekście wychowania, in: E. Kubiak-Szymorska, D. Zając (eds.), Wychowanie w kręgu pytań, Bydgoszcz 2013, p. 51.

${ }^{70}$ M. Majewski, Tajemnica żywotności Jana Bosko i Janusza Korczaka, p. 69-76. 
humanity. A child's freedom and individuality are personal traits resulting from the ontology of a child's being. Korczak respected this manifestation of humanity in the entire integral education ${ }^{71}$. An upbringing based on parental love and dialogue created a chance for the spiritual rebirth of a child who had been hurt and wounded in his humanity; furthermore, such an upbringing effectively helped develop and build up the child's spiritual and physical strength. The entire upbringing in an axiological and integral development way resulted from the personal subjectivity of a child's being. An educator, as a person open to a child, understanding him, capable of showing him love, kindness and unconditional acceptance, played an important role here.

Thus motivated upbringing led to creation of two models of a happy, fulfilled $\operatorname{man}^{72}$, namely 'socialized man' and 'mature man'73. A 'socialized man' is noted for his orientation towards others, an ability to understand them and communicate with them, which became a historical necessity. On the other hand, a 'mature man' is aware of what he lives for and what gives the most crucial meaning to his life; such a person accepts other people as they are, is ethically mature and acts consistently with the principles he believes in. In the context of Korczak's upbringing, these models were used primarily to shape humanity in a child, expressed through the axiology and ethics of life. It was an overriding action, to which upbringing-related goals and their practical accomplishment in Children's Homes were subordinated.

It seems that such a model of upbringing, well-tried by Korczak, is of extreme importance to the present because it indicates effective, affirming or, as we would say today, creative ways to develop a child's personality. One has to agree with J. Binczycka here, who notes that "the attraction of Korczak's thought and his very personality are still high and still valid; this is a psychological fact and as a sociological phenomenon it is worth considering and conducting further research. For there is a very strong need to converse with someone authentic, with a real man, and Janusz Korczak was such person beyond any doubt. Understanding his person and his ideas is a must for modern pedagogy" 74 .

\footnotetext{
${ }^{71}$ Cf. J. Niewęgłowski, Janusz Korczak dziecko i Bóg, p. 317 and 323-324.

${ }^{72}$ That man refers to person or to women alike.

${ }^{73}$ Cf. D. Rusakowska, Janusz Korczak o szkole..., p. 49.

${ }^{74}$ J. Bińczycka, Korczakowskie ślady i wzorce, „Ruch Pedagogiczny” (1998) 3-4, p. 99.
} 
Korczak's pedagogical approach includes many deep and accurate decisions sheding new light on the issues covered. Studies show that, essentially, his philosophy of upbringing coincides with modern pedagogy guidelines which seeks full answers to such questions as: who is the child as a person and an entity in upbringing and education? What is upbringing? And especially in this context, who is an educator?

The model developed by Korczak is highly important and significant to modern pedagogy which is looking for new 'human models' of functioning ${ }^{75}$. Today, in particular, we need a teacher, a tutor with a rich and positive personality ${ }^{76}$, centred around human values, a person who is an authority not only in the field of teaching, but above all in morality resulting from an ethical lifestyle. Contemporary teachers face the challenge of building an authority integrally connected with moral culture and the testimony of life. This construed authority becomes the basis for professional success and identity ${ }^{77}$.

J. Zimny claims that, for today's children and young people, the top-down imposed educational professionalism of a tutor or a teacher is not enough; neither is their knowledge erudition and all that makes up the intellectual constitution of a teacher ${ }^{78}$. This is why young people and their parents expect pedagogical mastery from tutors and teachers: that is empathy, understanding of a child, great pedagogical tact on top of the knowledge and experience, allowing them to get to know and understand a child. Moral authority is closely connected with the tutors' responsibility for themselves and for the other human being entrusted to their care; in today's world, such an attitude demands courage ${ }^{79}$.

Korczak introduces into pedagogy, into the world of dialogue with a child, a new tutor-teacher: this is a person with a mature personality, emotionally stable, confident, ready to continuously become human again $^{80}$, willing to devote one's entire 'self' to the process of upbringing. A rational educator, is a good person, driven by love for a child with trust, dialogue and emotional

75 J. Bińczycka, Spotkanie z Korczakiem, p. 73.

${ }^{76}$ Cf. J. Zimny, Autorytet nauczyciela XXI wieku, „Pedagogika Katolicka” (2007) 1a, p. 54.

${ }^{77}$ Cf. M. Tomczyk, Ideaty i wzory osobowe w ujęciu o. Jacka Woronieckiego, p. 302.

${ }^{78}$ Cf. J. Zimny, Autorytet nauczyciela XXI wieku, p. 51.

${ }^{79}$ Cf.: A. Rynio, Nauczyciel - między ideałem mistrzostwa a rzeczywistościa, in: K. Stępień (ed.), Zawód nauczyciel. Trudności, perspektywy, Lublin 2010, p. 25; J. Bińczycka, Spotkanie z Korczakiem, p. 68.

${ }^{80}$ Cf. B. Wojnowska, Korczak a wychowanie do pokoju, „Ruch Pedagogiczny” (2001) p. 101. 
openness. The key qualities that determine a tutor's ethos include: honesty, justice, moral purity, creative and positive attitude to different childraising related situations, empathy, understanding, consistency in setting requirements, willingness and openness to what is good and new, and the ability to observe and get to know a child ${ }^{81}$. According to Korczak's upbringing model, a contemporary tutor is not only required to permanently improve his professional career by, for instance, enlarging the scope of methods and forms of intellectual work and his own experience of but also to constantly work on himself, on his own character and moral standards.

Understanding Korczak's attitude to solving pedagogical problems is of great importance to today's pedagogy. He solved such problems through the analysis of causes, not effects, as it happens today. I. Jundziłł notes that any kind of disturbances in a child's conduct make adults pay attention to the nature of a child and to his wrong attitudes that need to be changed by means of various sanctions. However, the causes of disturbed behaviour should not be sought in manifestation of such disturbances (i.e. effects) but in real factors determining a child's conduct. Instead of changing the environment, as Korczak did, today, everyone, in their own way, tries to change a child ${ }^{82}$.

\section{Summary}

Korczak's approach to a child and his upbringing is reflected in the topicality of his pedagogy. When analysing the meaning of his theory and practice to contemporary pedagogy, it is worth noting that this topicality manifests itself in newness, timelessness and relevance. This means that Korczak's principle shave tremendous potential of topicality with regards to his ideas and concepts regarding a child, an educator and certain style of upbringing and education. Nowadays, their implementation requires new and well-thought-out ways and means.

Rev. M. Majewski notes that a request to acknowledge Korczak's ideas, style and concepts of education and upbringing as comprehensive, would not withstand criticism when compared to the contemporary pluralistic model of child-rearing based on a multiplicity of solutions. Therefore, it

${ }^{81}$ Cf. J. Bińczycka, Spotkanie z Korczakiem, p. 87-89.

${ }^{82}$ I. Jundziłł, Opieka nad dzieckiem w Polsce w świetle idei Janusza Korczaka, p. 29-30. 
seems impossible to suggest that Korczak's entire pedagogy is implemented in contemporary education and upbringing. There is a tendency in today's pedagogy to abandon systems in favour of selected ideas. Korczak's system is currently being analysed in terms of his concepts and practices combined into a systematic, ordered whole. Development of this system shows gradual improvement, more accurate structures and more precisely thought-out methods, which is why this pedagogy should be refined (for instance through explication of basic ideas) and then put to work in modern upbringing and education ${ }^{83}$.

There seems to be an urgent need today to implement Korczak's concept of child and his upbringing. M. Zmysłowska ${ }^{84}$ indicates current studies regarding a child being treated as an equal human being. These studies show that such task is the most difficult to fulfil, because in the mind of adults a child remains an immature being; therefore, it is not clear how to understand children, their subjectivity, upbringing, education or how to talk to them. Dissemination of Korczak's realistic and attainable model would help modern educators understand the essence of a child and childhood in the most critical moments that is, when adults have to decide who a child is to them, or why and for what purposes they want to raise the child. It would also positively change the way of thinking, which in turn, would facilitate the popularization of the personalistic style of upbringing for today's educational needs.

Implementation of this model involves proper dialogue conducted with a child. G. Koć-Seniuch ${ }^{85}$ notes that in modern school, the idea of dialogue in Korczak-spirit way is not too popular. There is, therefore, an urgent need to disseminate and reliably show such dialogue in terms of purposes and principles of operation, which would give new opportunities to build personal models of relationships between children and their caregivers.

It seems clear today that detailed analysis of Korczak's philosophy is becoming a purpose of scientific research. It is conducted not only in education but also in classical philosophy, theology, personalism, didactics, literature, thereby contributing to the creation of more and more a reliable

${ }^{83}$ Cf. M. Majewski, Tajemnica żywotności Jana Bosko i Janusza Korczaka, p. 69-82.

${ }^{84}$ M. Zmysłowska, Współczesność propozycji wychowawczych Janusza Korczaka, ,Problemy Opiekuńczo-Wychowawcze" (2010) 3, p. 36.

${ }^{85}$ G. Koć-Seniuch, Na dialogu wszystko się opiera, in: Korczakowskie dialogi, Warszawa 1999, p. 181. 
overall picture of his pedagogy; this is why it becomes more comprehensible now rather than a few decades earlier. However, its most important concepts (such as the concept of a child and approach to children) demand even further interdisciplinary analysis towards exact reconstruction.

Rev. B. Migdał, who took part in a conference at the Catholic University of Lublin in 1979 dedicated to the values of Janusz Korczak's pedagogy, pointed out that his idea contains a number of guidelines to be used in pastoral work. Korczak formulated the system of upbringing and education compatible with Christianity, although formally he was not himself a member of the Christian community. His attitude towards life was marked by ecumenism, which is reflected in his dedication to Jewish and Polish children ${ }^{86}$.

It seems that Korczak's Christian approach to raising a child is of great importance to research conducted today by Christian pedagogues, who study the behaviour of a child as well as his upbringing and education in the context of religiousness and transcendence. His concept of a child from an integral perspective, rich and still under-examined, seems particularly important. It becomes a signpost on the way towards full, holistic recognition of the essence of a child from a scientific point of view, which, in consequence, may lead to new discoveries in pedagogical theory and practice.

The creed concerns an integral and subjective presentation of a child as a human being, an individual approach to a child and all the rights he is entitled to. According to Korczak, the personal identity of a child is a fundamental issue underlying the ideal of man, which in turn is based on the belief in innate desire for good. He believed that a man by nature is guided by love, and that evil is removable if one works on his own character ${ }^{87}$. Hence the need to understand a child, to provide all children with adequate living and learning conditions. The methodology of care and educational work applied in his Homes was based on the subjectivity of a child, within with a child was becoming a full-fledged co-creator of his own life. This concept led to children's autonomy (observed in the Homes), which to this day remains a valid standard in educational care facilities ${ }^{88}$. It was based on a dialogue between an

86 Sympozjum korczakowskie, p. 7.

${ }^{87}$ B. Wojnowska, Wczesna publicystyka Janusza Korczaka, in: H. Kirchner, O. Klecel (eds.), Janusz Korczak. Pisarz-wychowawca-myśliciel , Warszawa 1997, p. 45.

${ }^{88}$ J. Balcerek, Janusz Korczak jako prekursor pedagogiki opiekuńczej, in: H. Kirchner, A. Lewin (eds.), Janusz Korczak. Życie i dzieło, Warszawa 1982, p. 186. 
adult and a child. B. Wojnowska notes that Janusz Korczak was a practitioner of dialogue, he pursued the principle of partnership between a child and an educator based on understanding. He showed how to listen to a child, how to discover him and get to know him ${ }^{89}$. In his times, the educational contact between a teacher and a pupil at schools was reduced to an intellectual, shortlived relationship (also based on treating children like objects) which turned education into an impersonal technique ${ }^{90}$. Korczak quickly noticed that it is necessary to talk to children, to enter with them into personal, emotional dialogue, with which is it much easier to get to know and understand a small child. The sense of subjectivity and agency, as well as the awareness that a child has an impact on his own life and the facility he lives in gave him the sense of security and opportunity to develop morally and spiritually; this is why children in Korczak's Homes felt safe and well ${ }^{11}$.

${ }^{89}$ B. Wojnowska, Korczak: nowa antropologia wychowania, „Więź” 4 (534) (2003), p. 166; B. Smolińka-Theiss, Janusz Korczak - pedagogiczne transgresje, „Pedagogika Społeczna” 1 (2007) p. 9.

${ }^{90}$ J. Bińczycka, Spotkanie z Korczakiem, Olsztyn 2009, p. 68.

${ }_{91}$ Cf. J. Bińczycka, Spotkanie z Korczakiem, p. 71. 